\title{
The Role of the Bologna Process in Defining Europe
}

\begin{abstract}
The question of what Europe is remains under-elaborated in the literature on European matters, which points to the necessity to explore a definition of Europe. This paper shows that it is not possible to resolve the problem around the meaning of Europe without considering its higher education developments. The Bologna Process is a recent European intergovernmental higher education project aiming to form the European Higher Education Area by making degrees compatible in its signatory countries. Additionally, some other countries beyond this Area also tend to take up the Bologna Process to converge their higher education structures. It is argued in this paper that the Bologna Process is essential in approaching the definition of Europe because this project expands European borders and promotes the idea of a common European identity within them. These changes are supplemented by building up tensions in the development of territory-identity compatibility in the growing Europe. Impossibility to solve these problems makes Europe dynamic in the Bologna Process, and points to the depth of the meaning the borders, delineated by the Bologna Process, convey. The paper is developed with the help of a relevant critical literature review and the analysis of the international Bologna Process documents since 1998.
\end{abstract}

\section{Introduction}

Paradoxically, more often than not the question of what Europe is remains underdeveloped in the literature that discusses European matters (e.g., Novoa and Lawn, 2002; Papatisba, 2009). It is unclear whether Europe is the European Union (EU), or a geographical Europe as part of the continent Eurasia, or the territory of the European Higher Education Area (EHEA). The lack of explanation in the literature of what Europe means suggests a common assumption about a shared understanding of Europe. A close analysis of the literature that does speculate around the meaning of Europe (e.g., Eder, 2006; Dale and Robertson, 2009) shows that such an assumption is erroneous, and a definition of Europe requires further exploration.

The aim of this paper is to investigate the following question: What role does the Bologna Process play in shaping the meaning of Europe? The Bologna Process or Bologna is a European intergovernmental project in the area of higher education to make degrees compatible and comparable in its 48 signatory countries that would, in its turn, facilitate the development of a so-called EHEA. A fully functioning EHEA is planned to be achieved by 2020. The EHEA includes mainly EU countries, as well as its nearby states spreading as far to the east as Kazakhstan and Russia, and as far to the south as Turkey ("EHEA," 2014). Moreover, the Bologna Process has had an impact on higher education systems in other parts of the world, such as Africa (Eta, 2014). This paper does not aim to develop some kind of definitive conceptualization of what should count as Europe. Rather it is meant to demonstrate that it is not possible to resolve the 
question of the essence of Europe without considering recent developments in higher education in the context of Bologna.

The interrelatedness of the image of Europe and its general education space not just higher education - is apparent in the literature. Specifically, some authors, such as Grek (2008), tend to use the concepts Europe and its education space interchangeably in their discussions of European education in the context of recent reforms. Equally important here are the claims that the construction of education space makes Europe governable (Lawn and Grek, 2012), and that education is associated with the 'fabrication' of Europe (Novoa and Lawn, 2002: p.3). Moreover, Europe and its education space seem to be interrelated in the sense that a European education space is not seen as one of many European issues (like, for example, economy, citizenship, etc) but rather as a growing main concern in Europe. Specifically, Grek (2008) argues that education became the center of European policy-making. These authors do not focus on higher education specifically but their claims about education overall imply a similar potential of higher education.

Exploring the role of the Bologna Process in shaping the meaning of Europe is significant and timely. Europe as a converged competitive area with distinct traditions and identity has been promoted through a number of political-economic initiatives, such as the establishment and enlargement of the EU, the Free Trade Association, the Economic and Monetary Union of the EU, to name a few (Wolczuk, 2009). The Bologna Process is the largest European initiative geography-wise, which has appealed to the facilitation of a European identity through educational matters. This initiative is distinct from other above mentioned projects in Europe. The Bologna Process is focused on higher education. It is also, arguably, the most straightforward path towards the facilitation of a European identity, since identity is mainly constructed through education (Field, 2003). Taking into consideration the idea about an ongoing development of Bologna, it is crucial for the higher education community of the current EHEA and other states that took up the Bologna Process to shift their attention from the Bologna Process performance indicators for a while. It is important for them to consider this study to be able to take a wider look at what has been happening, understand the role of the Bologna Process in shaping the essence of Europe and their share in its construction, and be fully informed about the opportunities and risks they have been facing in the Bologna Process.

This paper argues that the Bologna Process contributes to defining Europe by changing its geopolitics through expanding its borders and promoting the idea of a common European identity within them. This is accompanied by aggravating tensions in the development of a territory-identity integrity in Europe constructed by Bologna when identity of peoples residing on a certain territory is in line with the geopolitics of this territory. Impossibility to instantly achieve such a compatibility between the borders of the EHEA and identity of peoples within them makes Europe dynamic and constantly under construction in the Bologna Process.

The following structure of the paper supports the development of this argument. A critical literature review of how Europe tends to be viewed is presented first. This broad literature (not necessarily focused on higher education) points out a gap in the explanation of the meaning of Europe and highlights several conceptual ideas that build a theoretical ground for answering the main research question in this paper. This is followed by a review of literature about the Bologna Process that suggests the potential 
of Bologna to have a constitutive effect on the meaning of Europe. Further, the analysis of the Bologna Process international ministerial communiques and declarations as the main empirical method in this paper is explained. What is presented next is the findings about how the Bologna Process expands European borders, and what sort of European identity it promotes within these borders. It is also shown how the expansion of European borders and the promotion of a common European identity within them is accompanied by building up problems in the development of a territory-identity compatibility in Europe. The impossibility to solve this problem makes Europe remain in the process of creation in the Bologna Process context.

\section{Debates about Europe}

Dale and Robertson (2009) argue that a single view of Europe and what is meant to be European is absent. Indeed, most of the perspectives on what Europe is are concentrated around the idea of its borders. One example of this is the EU versus geographical Europe puzzle. Europe is very often used to denote the EU (Novoa and Lawn, 2002; Papatisba, 2009). This is the case even though geographically Europe spreads out further to the east from the EU border, encompassing some non-EU countries, such as Moldova, Ukraine, a small western part of Russia (Walters, 2009). Another example of how Europe is viewed through its borders is the debate around boundaries between the EU and non-EU countries. Eder (2006) distinguishes inner and outer boundaries of Europe, which are constructed by the peoples inside and outside the EU.

A specific example of this debate is the European Neighborhood Policy (ENP) countries. The ENP, developed in 2004, aims at avoiding the emergence of new dividing lines between the enlarged EU and our [EU's] neighbors and instead strengthening the prosperity, stability and security of all. It is based on the values of democracy, rule of law and respect of human rights' (EEAS, 2014). Initially, the ENP was arranged for the neighboring post-Soviet countries (Kochenov, 2011), but now the ENP is proposed to 16 closest neighbors of the EU (EEAS, 2014).

While most of the scholars who research the ENP look at the impact of the EU on the neighborhood states, some others take a slightly different position and dwell on the impact of the ENP states on the EU. On one hand, based on the quote above, the ENP countries can be seen as an integral part of Europe together with the EU. It is so because the countries that joined the ENP agreed to follow European values of democracy and the rule of law. On the other hand, the ENP is seen by some authors as a tool to draw another boundary around the EU and define that what is within the EU is European, and what is not within the EU is non-European and will never be. According to Browning and Christou (2010), the ENP states help to demarcate ultimate borders of the EU. This idea seems to contradict the one mentioned earlier about the ENP being a tool to avoid the emergence of new dividing lines between the EU and its neighbors. However, Browning and Christou's (2010) suggestion about some constitutive effect of the ENP states that have a label of non-EU states finds support in the literature. A similar idea is also expressed by Nikolaidis (2005) who claims that 'the major aim of this initiative is to create a ring of friends around the borders of the new enlarged EU' (p.6). The ENP does not offer any EU membership prospects to its participatory counties (Lavenex, 2008; Epstein and Sedelmeier, 2011). According to Kochenov 
(2011), it is so because the domestic situation, especially the level of democracy, in the ENP states is less conducive to meeting the EU conditionality than in the EU candidate countries.

Lawn and Grek (2012) acknowledge that the idea of borders is a typical way of conventional thinking about Europe because people tend to apply their conception of country boundaries to speculate about Europe. However, apart from the emphasis on the problem of borders that define Europe, these authors maintain that Europe is 'a space of meaning,' rather than 'merely a place' (p.13).

This paper relies on Lawn and Grek's (2012) notion of Europe as 'a space of meaning' that implies that both variants are two separate ways of viewing Europe. This paper takes the idea put forward by the authors further and suggests that Europe is, indeed, a space of meaning that, however, should not be viewed as an idea separate from the view that it is a place with borders. It should rather be seen as an idea including borders, which also shape the meaning of Europe.

The notion that borders are not purely geographical lines is also supported by Eder (2006) and Walters (2009). Eder (2006) argues that borders are both 'hard' and 'soft' lines at the same time (p.255). They are hard because, obviously, they are demarcated on a map. They are also soft because they are borders between people borders that are imagined, negotiated, and thus, socially constructed. The authors argue that both aspects of bordering interact because there is a two-way process 'from boundaries to identity and back to the real borders' (p.268). Similarly, Walters (2009) states that 'borders have become a meta-concept: all manners of social issues now find expression and connection in a language of boundaries, margins and frontiers' (p.485). Hence, the essence of Europe as a 'space of meaning' depends on the meaning which is attributed to it by those who reside within and beyond this space.

Lawn and Grek (2012) mention that the idea to view Europe as 'a space of meaning' is built on another concept - 'imagined community.' This concept is introduced by Anderson (1983) to explain nations and the phenomenon of nationalism (p.15). This notion relates to a more general context, not limited to Europe. Nations are imagined because all their members do not know one another, and yet they all consider themselves to be part of a communion. Nations differ because the ways in which they are imagined are distinct. And consequently, nationalism is not about awakening a nation, but rather about inventing a nation where it does not exist. These ideas of Anderson (1991), apparently, became a ground for Lawn and Grek (2012) to develop their notion of Europe as 'a space of meaning,' since the essence of Europe can be seen as depending on how it is imagined.

Another important point here is the fact that whatever Europe may be, it encompasses a number of countries. Regardless of the fact what space they cover, it is important to be mindful of the challenges around generating homogenous meaning of European-ness within this space. Building European identity in these different countries is key here. Derrida (1992) calls for looking at the European identity seeking process as building commonality along with the unavoidable respect of differences. The facilitation of commonality is argued by the author to be the case, given that cooperation tights among European countries have been growing in the post-Cold War era. Yet, the respect to diversity is seen by the author to be taking place, and is recognized by him to be the only possible way for commonality in Europe to be 
promoted. The author maintains that centralized authority in this process cannot be established because it would undermine the respect to diversity which makes an integral part of European identity. Derrida's (1992) ideas pertain to political developments in Europe after the Cold War. Similarly, a more recent study by Eriksen and Fossum (2007) contains a reference to European integration as 'a union of deep diversity' (p.6).

Further discussion in this paper suggests that borders, besides being a typical way of looking at Europe, convey certain meanings and should be seen as an inherent part of the definition of Europe as 'a space of meaning.' Actually, borders gain or rather maintain their constitutive effect on the definition of Europe. Geography cannot be seen as neutral and unaffected by politics, which is essential in the debates outlined above even though these debates emphasize geographical problems. This paper further discusses the role of higher education in the context of Bologna in defining Europe. Both the expansion of the territory of Europe and the promotion of a common identity within it in the Bologna Process context should be seen as part and parcel of the space of meaning of Europe. These developments are intertwined since geography and politics of the EHEA seem to go hand in hand.

\section{The potential of Bologna to construct the meaning of Europe}

Having demonstrated that a comprehensive explanation of what Europe means is missing in the literature, it is now important to analyze how Europe is positioned in relation to the Bologna Process in relevant literature. The analysis below will show that the Bologna Process is presented in the literature as having a potential to impact the meaning of Europe.

Since the image of Europe and its higher education might be related (Grek, 2008), it is important to look at how exactly the Bologna Process is evaluated in the scholarship. It suggests that Bologna has been expanding in terms of the number of countries that join it, as well as in terms of the initiatives that Bologna becomes associated with.

Since its inception, Bologna has attracted new member states and new international stakeholders, according to Terry (2010). The authors argues that initially, Bologna was suggested by ministerial representatives of four western European countries such as the United Kingdom, Germany, France and Italy. They got together in 1998 in the honor of the Sorbonne University anniversary. They decided to call upon other countries to join them in the initiative to build the EHEA. Currently, 48 countries, mainly the EU states and a number of its nearby countries, are working to implement the Bologna Process, and thus, to develop the EHEA (see figure 1 below). Monaco and San Marino are the only two states in this space that have not yet obtained membership in the EHEA. Besides the ministries of education in the membership countries, there is a number of international stakeholders that became involved in the support of the development of the EHEA, such as the European Commission, the European Students' Union and others.

There are also countries in other parts of the world that have chosen to follow Bologna or are considering doing so. Specifically, there is research about the adaptation of the Bologna Process in a region in Africa (Eta, 2014). The Economic and Monetary 
Community of Central Africa emerged with the aim to promote cooperation among its members. It currently includes the following countries: Cameroon, Central African Republic, Chad, Republic of Congo, Equatorial Guinea and Gabon. People in this region speak a common language which is French, use common currency, and have a common passport. To further integrate the countries that compose this economic and political union, the Bologna Process has been taken up (Eta, 2014). Beside the spread of the Bologna Process in Africa, it is obvious from the literature that the Bologna Process is also a matter of interest in the USA and some countries of South America (Terry, 2007). Less interest is expressed by east Asian countries. However, there are already studies investigating the readiness of, for instance, China and the Association of South Eastern Asian Nations for the Bologna Process (Zeng et al, 2013). This interest in the Bologna Process in different parts of the world suggests that Bologna is actually quite likely to spread even beyond the borders it has reached by now in the EHEA.

Figure 1: The countries of the EHEA

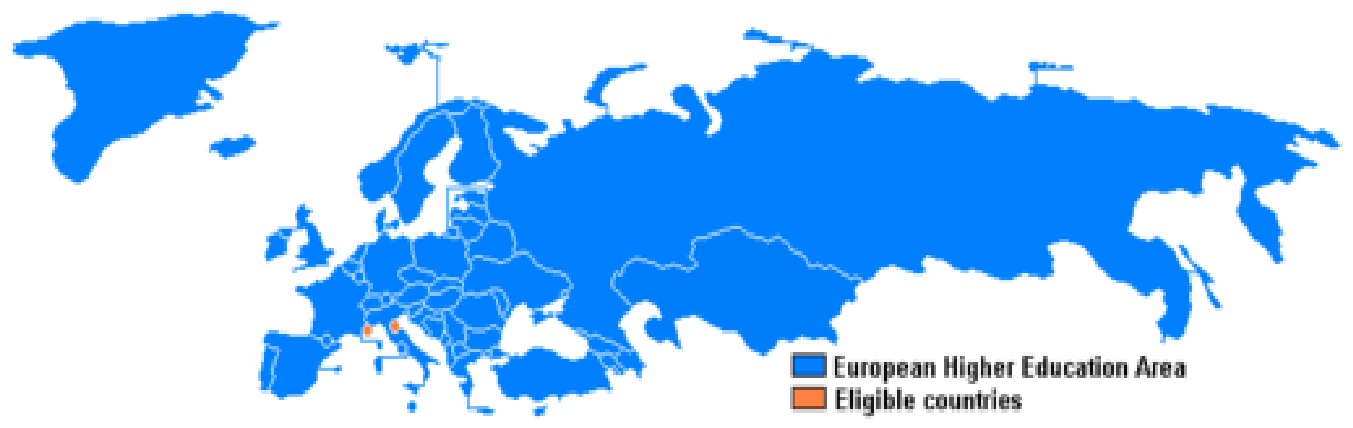

Source: ("EHEA," 2014)

Apart from attracting new member states and new international stakeholders, Bologna has expanded the number of its objectives and clarified relevant meanings since its inception. Thus, the Bologna Process is becoming the biggest and most influential higher education initiative. In particular, Vogtle and Martens (2014) claim that the Bologna Process 'presents the largest ongoing reform initiative in higher education' (p.246). This important status of the Bologna Process may be at least partially attributed to the idea that the Bologna Process acts like a snowball, attaching other initiatives to itself as it develops. This is implied by Dobbins and Knill (2009) who state that '...it is often difficult to disentangle Bologna from... related convergence-promoting factors... These include, to mention a few, cooperation with the Organization of Economic Co-operation and Development (OECD) and World Bank' (p.398). There is also a similar argument in favor of the multiplicity of higher education reforms over the last years, with the main goal of all those reforms being the establishment of common reference points in higher education systems in European countries (Stiwne and Alves, 2010). Moreover, the EHEA seems to encompass other emerging areas which have not gained as much momentum as the EHEA but which are still recognized to be associated with European higher education. For instance, the European e-Learning Area is argued to be developing in result of the eLearning Program promoted by the European Commission and to be governed by similar arrangements as the EHEA (Salajan, 2013). This similarity can be hypothesized to stem from the superior status of the EHEA. Likewise, the European Research Area was initiated in the framework of the Lisbon Agenda since 2000 targeting economic competitiveness of Europe. The European Research Area eventually got affiliated with 
the EHEA, which became an umbrella notion even for the whole Lisbon Agenda (Huisman and Van der Wende, 2004; Corbett, 2011).

The encapsulation of all of the above analyzed initiatives in the Bologna Process has aimed at the development of a European identity in the Bologna countries (Papatsiba, 2009). The discussions of the image of the student and the image of the citizen in the Bologna Process literature coincide. Flexibility and mobility are now seen as essential characteristics of both the student (Brine, 2006) and the citizen (Papatsiba, 2009). The relationship between the development of citizen's and student's identities is justified by Zgaga (2009). The author claims that 'citizenship is a concept inherent to the idea of the university and the role of higher education' (p.177). The connection between the development of citizen's and student's identities is also implied by Papatsiba (2009) who claims that flexible and mobile citizens are formed through education mobility programs. Moreover, the construction of a European citizen through Bologna happens in opposition to the construction of 'the other' - someone who is excluded and in relation to whom the European citizen should be competitive (Fejes, 2008). This author further argues that the 'other' is then constructed though the narrative about being devoid of the characteristics that the European citizen has flexibility, autonomy and self-regulation. However, according to the author, although Bologna aims to converge higher education structures and as a result the characteristics of European citizen cultivated thought higher education, diversity in higher education traditions is respected. This is in line with the arguments of Derrida (1992) and Eriksen and Fossum (2007). It was explained earlier that these authors state that Europeanisation more widely has been linked to convergence in certain aspects, while others remained unchanged, and this resilience was respected. This perspective on European integration in general as well as specifically in the context of the development of Bologna moves away from an either-or perspective taken by a number of other authors who analyze Bologna.

Such a dualistic position can be traced in the following. One group of scholars recognizes evolving convergence in the EHEA in the context of the loss of diversity. To illustrate this, Field (2003) and Pyykko (2008) maintain that the Bologna Process is a threat for national higher education systems, cultures and identity, given the need to change program and course content within Bologna. Additionally, this literature also acknowledges an opposite case - when diversity is perpetuated through limited convergence. In particular, another group of scholars, such as Portela et al (2009) and Zgaga (2009), states that higher education systems in the Bologna Process countries undergo mainly technical implementation of reforms without much change in essence because of the absence of strict control over the Bologna Process implementation and because of the persistence of countries' cultural, historical, economic and political contexts. Thus, a European identity in the EHEA is not facilitated, since not much convergence is triggered by the Bologna Process.

\section{Further investigation of Europe in Bologna}

The analysis of the literature above has demonstrated that Bologna may be contributing to the construction of the meaning of Europe. To explore how exactly it can do so, document analysis was conducted. The collection and analysis of the Bologna Process international ministerial communiques and declarations is the main 
empirical method in this paper. In total, nine documents were considered: Sorbonne declaration (1998), Bologna declaration (1999), Prague communique (2001), Berlin communique (2003), Bergen communique (2005), London communique (2007), Leuven-Louvain-la-Neuve communique (2009), Budapest-Vienna declaration (2010) and Bucharest communique (2012). These documents were produced at international ministerial Bologna conferences. As it is apparent from the publication date of these documents, the conferences tended to take place every two-three years since the inception of Bologna. These documents were collected from the official website of the EHEA ("EHEA," 2014).

All of these documents were thematically analyzed. Themes as units of analysis are useful for interpretation (Merriam, 2009), and for uncovering meanings (Rubin \& Rubin, 2012). The information in the documents was manually coded around such broad categories as synonyms of the notion Europe, territory of Europe, European identity and citizenship. These categories were chosen because they appeared to be the most prominent in a discussion about Europe in the literature presented above.

\section{Bologna expanding the borders of Europe}

This section presents the analysis of the Bologna declarations and communiques. This analysis supports the idea already suggested in the literature - that Bologna has a potential to contribute to making the meaning of Europe. Moreover, the analysis conducted on the Bologna documents demonstrates that Bologna shapes the meaning of Europe which is associated with European borders and identity of the peoples within them. Bologna expands European borders. This analysis also shows that the promotion of a common European identity within these widening borders is accompanied by building up problems in the development of a territory-identity compatibility in Europe. The impossibility to solve this problem makes Europe remain in the process of creation in the Bologna context.

European borders developed and changed in the course of the Bologna Process. Europe and the EHEA are used interchangeably in all Bologna documents that were analyzed (e.g., Bologna Declaration, 1999; Prague Communique, 2001; Berlin Communique, 2003; London Communique, 2007). The EHEA and thus Europe used to be associated in the beginning only with the EU. For instance, it is stated in the Sorbonne Declaration (1998) that 'the fast growing support of the European Union, for the mobility of students and teachers, should be employed to the full' (p.2). Europe in the Bologna Process was seen in terms of the EU back in 1998 as the first signatory countries were the EU countries - Germany, Italy, France and the United Kingdom. A year later, when more countries joined the Bologna Process, a 'growing awareness... of the need to establish a more complete and far-reaching Europe' was mentioned in the Bologna Declaration (1999: p.1). Further, the enlargement of the EU was recognized in the Prague Communique (2001) as a reason for involving more countries into the Bologna Process. The idea of the EU expansion was never mentioned afterwards in the following Bologna documents perhaps because too many non-EU countries started joining the Bologna Process. Apparently, some of them were not seen by the EU representatives as having a potential to join the EU. This is, arguably, a turning point in moving away from the conceptualization of Europe in terms of the EU in the Bologna Process. Europe turned to be about the whole growing EHEA, which was at each point 
of its development clearly demarcated from the rest of the world with which the EHEA was supposed to compete in excellence (Berlin Communique, 2003).

The Bologna Process expands European borders more than any other recent initiative discussed earlier. It also shapes a particular meaning of Europe - Europe where the ideas of common European values and a common European identity are developed. European values seem to be a foundation of European identity - acceptance of European values makes a foundation of European identity.

European values are discussed in the Bologna documents around the ideas of democracy, freedom, 'belonging to a common social and cultural space,' respect to diversity (Bologna Declaration, 1999: p.1). Another European value is geopolitical standing of Europe that aims to respect everyone beyond its borders and support everyone within its borders. It also aims to be distinct in the world by becoming the most competitive knowledge economy in the world (Prague Communique, 2001). European values also comprise openness to ideas and knowledge, improvement (Bergen communique, 2005). The importance of European values in the EHEA can be traced in the fact that only countries that are party to the European Cultural Convention have been eligible to join the Bologna Process (Budapest-Vienna Declaration, 2010).

A European identity in the EHEA is based on these values. It was suggested in the literature review above that mobility and flexibility are now supposed to be the main characteristics of both students and citizens. The analysis of the Bologna documents adds that the European identity means the development of the image of a lifelong flexible mobile student whose constant self-improvement enriches a positive appearance of Europe and its worldwide competitiveness. Specifically, 'we see the development of national and European frameworks for qualifications as an opportunity to further embed lifelong learning in higher education' (Bergen Communique, 2005: p.3). Furthermore, the EHEA aims to prepare 'the student for the labour market, for further competence building and for active citizenship' (p.6).

The promotion of such a commonality in the EHEA has been happening at the same time as the promotion of the respect to diversity in cultures, languages, national higher education systems and university autonomy. Specifically, it is stated in Bologna Declaration (1999), "we hereby undertake to attain these objectives - ...taking full respect of the diversity of cultures, languages, national education systems and of university autonomy - to consolidate the European area of higher education' (p.3). This respect to diversity might seem to be quite an odd basis for promoting a common identity. Generating convergence might be easier in the context of abandoning diversity, since it seems to be an antithetical phenomenon to convergence. This and other challenges in promoting a common European identity will be further discussed below.

Europe has been dynamic because the territory-identity integrity problem of Europe in the Bologna Process has been gradually developing with the expansion of European borders. For instance, Russia's membership in the EHEA is an interesting case. Its authoritarian government and anti-western ideology (Kuzio, 2012) seems to be at odds with the European values, associated with the respect to diversity, mentioned above. Solutions to this discrepancy between one growing space and non-unified identity of its peoples have been sought for but never found. This argument adds to the idea of Lawn and Grek (2012) who suggest that Europe is dynamic because the identification of its essence is always pursued by interested parties. This vision of a 
European identity by Lawn and Grek (2012) can well be applied to what is happening with it specifically in the Bologna Process context. Convergence in the EHEA, coupled with the preservation of diversity, might be the tension that makes the overarching essence of a European identity in the EHEA.

Both convergence and respect to diversity are advocated in international ministerial documents (e.g., Bologna Declaration, 1999; Budapest-Vienna Declaration, 2010). Therefore, an earlier mentioned Derrida's argument (about the integration process in Europe happening while preserving diversity) can have value in the case of Bologna. The declaration of the respect of diversity in the context of convergence, which might be seen as bounded in such circumstances, can be viewed as conducive to the involvement of more and more countries in the Bologna Process. Since the timing of the involvement of the Bologna Process signatory states differs, so must the respect to diversity in these countries. The countries that joined later, apparently, had to agree to a set of conditions for convergence already set without them (such as a certain system of study cycles, credit system, university autonomy, etc). So hypothetically, the degree of respect to diversity that newer countries should demonstrate is perhaps bigger than that of the countries that have been in the Bologna Process for a while. The respect that the countries that are already party to the Bologna Process should demonstrate is in relation to the variations of the implementation of the Bologna Process ideas among themselves. This respect should be also demonstrated in relation to newly joined countries, which would need time to go through reform processes to reach the level of convergence that exists among the countries which joined the Bologna Process earlier.

This idea is aggravated by the inviting nature of the Bologna Process, which respects differences of all the countries it has involved but, at the same time, overlooks these differences to an extent because of the promoted convergence. All of this suggests the necessity to speculate whether this has to do anything with the past colonial role of Europe. Apparently, the term 'colonialization,' if defined as pertaining to forceful invasion, is inappropriate in the Bologna context. The Bologna Process is based on voluntary involvement and participation. This is despite the fact that voluntarism involves conforming to peer-pressure and seeking for ways to solve national problems in higher education and beyond, which drive the Bologna Process joining and participation at least in Easter and Central European countries (Zgaga, 2009). However, voluntarily giving up some freedom in steering national higher education for the sake of the benevolent EHEA goals, explained earlier, and bearing with wider consequences it yields, makes the Bologna Process be both a benign, and possibly a risky project for the signatory countries, as detailed below.

The promotion of a seemingly benevolent idea of a European identity within a growing EHEA might be seen as placing some countries into the periphery, especially those located beyond the boundaries of the EU or even the geographical Europe. This suggests that the debate on common values that stem from common history of European countries (Berlin Communique, 2001) is foreign to these states. These countries should then respect the idea of a European identity more than 'non-peripheral' European countries need to respect the identity of these countries, which need to work towards the facilitation of a European identity. This suggests some sort of regionalization in the EHEA. There are those countries that need to respect more and those countries that need to be respected more. Such a misbalance of power among the members of the EHEA is perhaps both a result of the expanding European borders and part of the meaning of Europe in the Bologna context. 
All of these examples support the idea that European borders contribute not merely to the delineation of its territory, but also to the construction of the meaning of Europe through developing the European identity. They also show how the expansion of European borders and the promotion of a common European identity within them is accompanied by building up problems in the development of a territory-identity compatibility in Europe constructed by the Bologna Process. Impossibility to instantly tackle this problem and the necessity to look for a solution makes Europe stay dynamic in Bologna.

\section{Conclusion}

Placing the Bologna Process at the center of analysis in the speculations around Europe has allowed showing that European borders are being expanded. It has also helped to see that the meaning of Europe is shaped in Bologna through the development of a European identity. This identity is linked to an unreconciled struggle between convergence and the preservation of divergence within them. Expanding borders and the tensions associated with the European identity make Europe dynamic and constantly under construction in the Bologna Process. This research, exploring the role of the Bologna Process in shaping the meaning of Europe, is significant and timely for the higher education community of the states that joined the Bologna Process because they need to take a wider look at the Bologna Process and understand broader implications of the continuation of the spread of the Bologna Process. They should understand the role of the Bologna Process in shaping the essence of Europe and their share in its construction, and they should be fully informed about the opportunities and risks they have been facing while being involved in the Bologna Process.

Further research is needed to identify differences in the role of the Bologna Process in the creation of Europe within and beyond the EHEA, such as in Africa and South America. This should be followed by attempts to integrate research on defining Europe from multiple perspectives to arrive to an abstract conceptualization of what counts as Europe. This is essential for further understanding of the political processes where a currently fragmented and vague entity referred to as Europe is involved. 


\section{References}

Anderson, B. (1983). Imagined Communities: Reflections on the Origin and Spread of Nationalism. London: Verson.

Bechev, D. (2011). Of Power and Powerlessness: The EU and its Neighbors. Comparative European Politics, 9.4/5, 414-431.

Bhabha, H. (1990). Introduction: Narrating the Nation, in Bhabha, H. (eds.). Nation and Narration. London: Routledge.

Bologna Declaration (1999). Retrieved from http://www.ehea.info/Uploads/Declarations/BOLOGNA_DECLARATION1.pdf (accessed October 1, 2014).

Borzel, T. (2011). When Europe Hits... beyond its Borders: Europeanization and the Near Abroad. Comparative European Politics, 9.4/5, 394-413.

Brine, J. (2006). Lifelong Learning and the Knowledge Economy: Those that Know and those that do not - the Discourse of the European Union. British Educational Research Journal, 32.5, 649-665.

Browning, C. and Christou, G. (2010). The Constitutive Power of Outsiders: The European Neighborhood Policy and the Eastern Dimension. Political Geography, 29, 109-118.

Budapest-Vienna Declaration (2010). Retrieved from http://www.ehea.info/Uploads/Declarations/Budapest-Vienna_Declaration.pdf (accessed October 1, 2014).

Corbett, A. (2011). Ping Pong: Competing Leadership for Reform in EU Higher Education 1998-2006. European Journal of Education, 46.1, 36-53.

Dale, R. and Robertson, S. (2009). Globalisation and Europeanisation in Education. Oxford: Symposium.

Derrida, J. (1992). The Other Heading: Reflections on Today's Europe. Bloomington and Indianapolis: Indiana University Press.

Dobbins, M. and Knill, C. (2009). Higher Education Policies in Central and Eastern Europe: Convergence toward a Common Model? Governance, 22.3, 397-430.

Eder, K. (2006). Europe's Borders: The Narrative Construction of the Boundaries of Europe. European Journal of Social Theory, 9.2, 255-271. 
EEAS, About us, European Neighborhood Policy http://eeas.europa.eu/enp/aboutus/index_en.htm (accessed November 24, 2014).

EHEA official website. (2014). Retrieved from http://www.ehea.info/ (accessed October 17, 2015).

Epstein, R. and Sedelmeier, U. (2011). Beyond Conditionality: International Institutions in Postcommunist Europe after Enlargement. Journal of European Public Policy, $15.6,795-805$.

Eriksen, E. and Fossum, J. (2007). A Done Deal? The EU's Legitimacy Conundrum Revisited. RECON Online Working Paper 2007/16. Retrieved from http://www.reconproject.eu/main.php/RECON_wp_0716.pdf?fileitem=50511941 (accessed October 17, 2015).

Eta, E. (2014). Policy borrowing and transfer, and policy convergence: justifications for the adoption of the Bologna Process in the CEMAC region and the Cameroonian higher education system through the LMD reform. Comparative Education, 50.4, 417-432.

Fejes, A. (2008). European Citizens under Construction: The Bologna Process Analysed from a Governmentality Perspective. Educational Philosophy and Theory, 40.4, 515-530.

Field, H. (2003). Integrating Tertiary Education in Europe. Annals of the American Academy of Political and Social Science, 585, 182-195.

Ganze, S., Meister, S., and King, C. (2008). The Bologna Process and Its Impact on Higher Education at Russia's Margins: the Case of Kaliningrad. Higher Education, 57, 533-547.

Grabbe, H. (2001). How does Europeanization affect CEE governance? Conditionality, diffusion and diversity. Journal of European Public Policy, 8.6, 1013-1031.

Grek, S. (2008). From Symbols to Numbers: The Shifting Technologies of Education Governance in Europe. European Educational Research Journal, 7.2, 208-218.

Huisman, J. and Van Der Wende, M. (2004). The EU and Bologna: Are Supra- and International Initiatives Threatening Domestic Agendas? European Journal of Education, 39.3, 349-357.

Kochenov, D. (2011). New Developments in the European Neighborhood Policy: Ignoring the Problems. Comparative European Politics, 9.4/5, 581-595.

Kuzio, T. (2012). Twenty years as an independent state: Ukraine's ten logical inconsistencies. Communist and Post-Communist Studies, 45.3-4, 429-438.

Lavenex, S. (2008). A Governance Perspective on the European Neighborhood Policy: Integration beyond Conditionality? Journal of European Public Policy, 15.6, 938955. 
Lawn, M. and Grek, S. (2012). Europenizing Education: Governing a New Policy Space. Oxford: Symposium.

London Communique (2007). Retrieved from http://www.ehea.info/Uploads/Declarations/London_Communique18May2007.pd $\underline{\mathrm{f}}$ (accessed October 1, 2014).

Merriam, S. B. (2009). Qualitative Research: A Guide to Design and Implementation. San Francisco: Jossey-Bass.

Nikolaidis, A. (2005). European Neighbourhood Policy - EU and Ukraine: Neighbour, Partner, Member? Retrieved from http://www.isn.ethz.ch/DigitalLibrary/Publications/Detail/?ots591=0c54e3b3-1e9c-be1e-2c24a6a8c7060233\&lng=en\&id=26515 (accessed November 4, 2014).

Novoa, A. and Lawn, M. (2002). Introduction, in Novoa, A. and Lawn, M. (eds.). Fabricating Europe: the formation of an Education Space. London : Kluwer Academic Publishers

Papatsiba, V. (2009). European Higher Education Policy and the Formation of Entrepreneurial Students as Future European Citizens. European Educational Research Journal, 8.2, 189-203.

Prague Communique (2001). Retrieved from http://www.ehea.info/Uploads/Declarations/PRAGUE_COMMUNIQUE.pdf (accessed October 1, 2014).

Pyykko, R. (2008). 'Bachelors for Europe, Specialisty for the Fatherland': Bologna through Russian Eyes. Slavica Helsingiensia, 35, 331-337.

Rubin, H. J. and Rubin, I. (2012). Qualitative Interviewing: The Art of Hearing Data (3rd ed). Thousand Oaks, Calif: SAGE.

Salajan, F. (2013). Policy formulation and networks of practice in European eLearning: the emergence of a European E-Learning Area. European Journal of Education, part II, 292-310.

Sorbonne Joint Declaration (1998). Retrieved from http://www.bolognabergen2005.no/Docs/00-Main_doc/980525SORBONNE_DECLARATION.PDF (accessed October 1, 2014).

Stiwne, E. and Alves, M. (2010). Higher Education and Employability of Graduates: Will Bologna Make a Difference? European Educational Research Journal, 9.1, 32-44.

Terry, L. (2007). The Bologna Process and Its Implications for U.S. Legal Education. Retrieved from http://www.personal.psu.edu/faculty/l/s/lst3/AALS_bologna_article.pdf (accessed November 24, 2014).

Vogtle, E. and Martens, K. (2014). The Bologna Process as a template for transnational policy coordination. Policy Studies, 35.3, 246-263. 
Walters, W. (2009). Europe's Borders, in Rumford, C. (ed.) Sage Handbook of European Studies, London: Sage.

Wolczuk, K. (2009). Implementation without Coordination: The Impact of EU Conditionality on Ukraine under the European Neighborhood Policy. Europe-Asia Studies, 61.2, 187-211.

Zeng, Q., Adams, J. and Gibbs, A. (2012). Are China and the Association of South Eastern Asian nations ready for the Bologna Process. Educational Review, 65.3, 321-341.

Zgaga, P. (2009). Higher Education and Citizenship: 'The Full Range of Purposes.' European Educational Research Journal, 8.2, 175-188. 
